\title{
架橋ポリエチレンの直流破壊電圧に及ぼす アセトフェノンの影響
}

\author{
正員速水 敏 圭 (住友電工)
}

\section{1.まえがき}

最近, 直流送雷用として架橋ポリエチレンなビのプ ラスチック絶縁ケーブルの適用が検討されているが，


強度が低下することや，V-t 特性がこう配をむつこと などが報告されている(1)。

また，厚肉の架橋ポリエチレンは空間電荷の形成に より極性反転時の特性が想念され，乙の分野の基整研 究の報告多多くなっている( ${ }^{(2)}$ 。しかし，架橋ポリエ于 レンの直流特性汇対要る上記原因の究明や性能向上の 扎めの検討はまだ十分行な的てていない。

一方，架橋ポリエチレンは架橋成の分解残查である アセトフェノンなよ゙か總縁体中に含ま机ているが， 筆者は，このアセトフェノンが表面效果に上り，交流

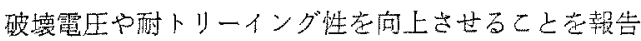
した (3)(4)。今回は，架橋ポリエチレンの主として直流 破塄電压に及ぼすアセトフェノンの影響について榆討 した結果索報告する。またアアセトフェノンだけでは


卞液体添加郕の效果芯調べた。

\section{2. 試料むよび実験方法}

試料はポリエチレンチューブ及び架禁ポリエチレン ケーブルを用いた。チューブはメルトインデックスが 1.2 ，密度が 0.92 の低密度术りエチレン在用い，内但 $2.0 \sim 2.3 \mathrm{~mm}$ で絶縁厚が $0.5,0.7,1.0 ， 1.5 ， 2.0$, $3.0 \mathrm{~mm}$ の6㮐類のチューブを製作した。このうち,

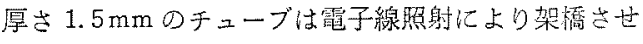

The Infuence of Acetophenone on the DC Breakdown Voltage of Crosslinked Polyethylene. By Toshiyuki Hayami, Member (Sumitomo Electric Industries, Ltd.).

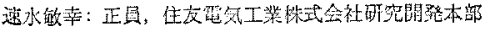

た。このときの試料の架槅度を示すゲル分率は 50〜 60\%であった。

試験峙には第1図に示すように，チニーブの内㑡に 直径 $1 \mathrm{~mm}$ の銅線を差し込み，すき宗に小量の界面活 性都を混ぜた氷を注入し内部電極とした。

ケーブル試料は同じく第 1 图に示すように，筫体が 直径 $1 \mathrm{~mm}$ の 7 本よりて，愿さ $1.5 \mathrm{~mm} の$ 架槁格リエ チレン（架橋用による化学架橋）を被稪したそデルケ ーブルを用いた。この架橋ポリエチレンモデルケーブ

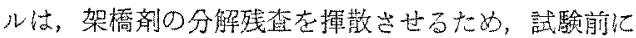
$80^{\circ} \mathrm{C} 3$ 日の乾燥を施した。

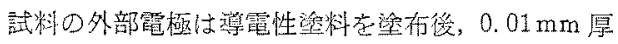

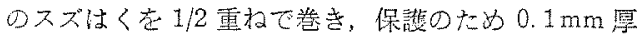
のポリエチレンテープ巻いた。

これらの䞑料は外部電極老施す前に液体走吸收させ たが，液体ば主としてアセトフェノンを用いた。

比校ししてシリコーン淊, OF ケーブル油, DOSを

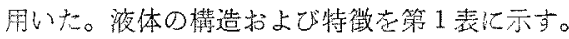

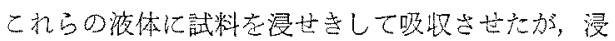
器条件はアセトフェノン，OFケーブル油，DOSは

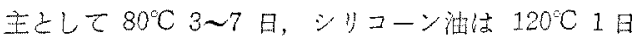
とした。
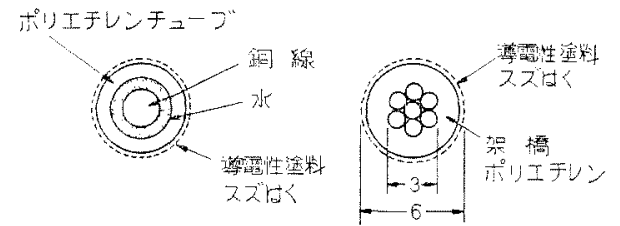

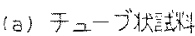

(b) モデルケーブル 最诘: $\mathrm{mm}$

第 1 四試料の形状

Fig. 1. Test arrengement. 


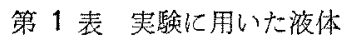

Table 1. Liquids used for test.

\begin{tabular}{|c|c|c|}
\hline 源 & 蒜造术よび特徽 & 粘 度 \\
\hline アセトフェノン & $\begin{array}{c}\mathrm{CH}_{3} \\
! \\
\mathrm{C}=\mathrm{O}\end{array}$ & $\begin{array}{l}\text { (cs) } \\
\text { 約 } 1\end{array}$ \\
\hline シリコーン油 & ジメチルシリコーン神 (信越 KF-96-10cs) & 10 \\
\hline OF ケーブル湆 & 鉱油，炭化水等系絶緣油 & 10 \\
\hline D $0 \mathrm{~s}$ & ジオクチルせバケート & 20 \\
\hline
\end{tabular}

OF ケーブル油，DOS，シリコーン油吸収試料は， $1.5 \mathrm{~mm}$ 厚の照射架樗ポリエチレンチューブを用いた。 試娩は主として尊体側負極性で $500 \mathrm{~V} / \mathrm{s}$ で昇圧する短 時間直流破買試験を行なった。試料長は $1.5 \sim 2.0 \mathrm{~m}$ (電極長 $0.5 \mathrm{~m}$ ) とし，少なくとも1条件 4 点とした。

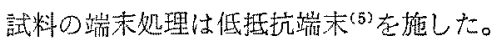

温度特性走とる場合は恒温油そうに試都を入れ，周 国谋体としてシリコーン油を用いた。常温以下の温喥 はドライアイスで泠却しだ。

\section{3. 実験結果}

\section{〈3.1〉破壊電圧の絶縁厚依存性蓑ずポリエチ} レンの各液体浸さき時の膨潤度（吸収量）温度特性

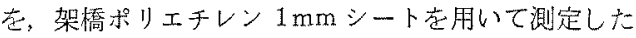
結果を第 2 图儿示す。

この結果， $80^{\circ} \mathrm{C}$ ではア七トフェノン, DOSが約 10 $\%$ ，OF ケーブル油は約 100\% 膨潤するととになる。 シリコーン油は $80^{\circ} \mathrm{C}$ 付近ではほ上んど吸収しない

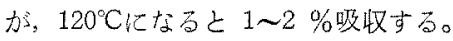

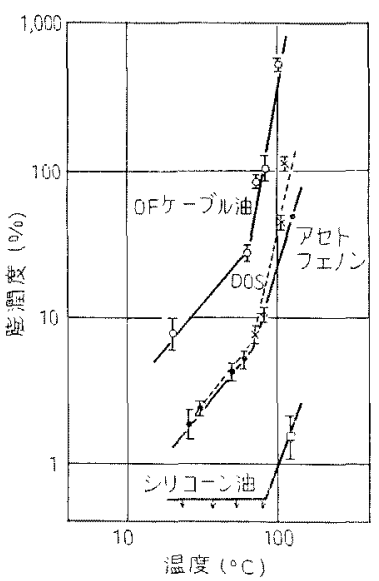


温度特性

Fig. 2. Swelling-temperature characteristics of crosslinked polyethylene.

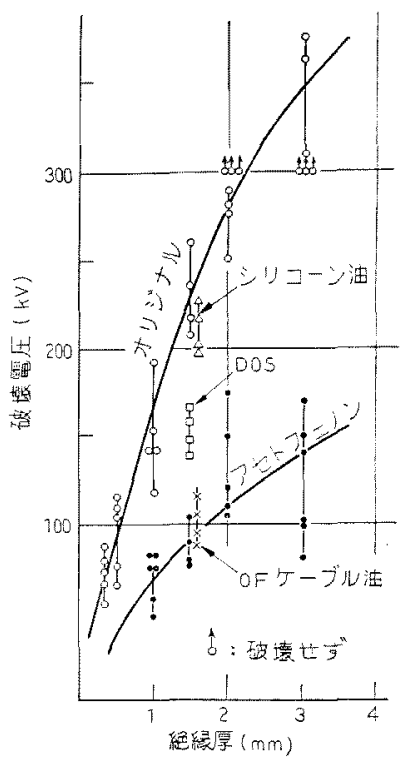

第3 図 直流破壊電压に及液体 吸取の影響

Fig. 3. Intluence of liquids absorption on DC breakdown voltage.

液体を吸取させた試料は常温中に取出して電極や端

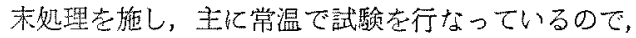
試験時の吸収量は第 2 区心值よりも少ないと考えられ 万ため，各試料の液体吸収量は破㙲試駼後重量測定法 により調ベだ。

常温 $\left(22 \sim 27^{\circ} \mathrm{C}\right)$ に放ける破壊試駼結果を厚さ特性 で表わすと第 3 図に示すようになる。このときの服收 量第2表化示す。

この結果，アセトフュノン定吸収さすと著しく直流 破境電王が低下することがわかった。OFケーブル油， DOS b直流では低下する傾向を示す。シリコーン油 は吸収量が微量なせいかほとえど変化しない。

この結果，直流破填篦王に対してはアセトフェノン わ゙最すセンシティブと䛓える。

なお後述するが，アセトフェノンの絶縁体中の分布

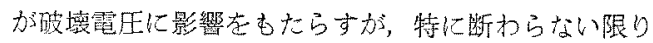
ここでは一様分布しているものとする。

第 2 表 第 3 区日試料の吸收最

Table 2. Swelling content of samples.

\begin{tabular}{|c|c|}
\hline 波 & 吸仅盕 $(\%)$ \\
\hline$r+ト>=\gamma$ & $4 \sim 7$ \\
\hline OEFケーブル油 & 50 \\
\hline O & $5 \sim 3$ \\
\hline シリコーン 淮 & $0.8 \sim 1.0$ \\
\hline
\end{tabular}


また，第 3 図 $1.5 \mathrm{~mm}$ 厚纳照射ポリエチレンの值で あるが、ポエチレン陚料の直線上にプロットできた。 後述する $1.5 \mathrm{~mm}$ 厚架橋ポリエチレンモデルケーブル す分解残查を擩散させるとポリエチレンと同等の值に なることなどから，前報の交流破壊電生 ${ }^{(3)}$ と同様に真 流破壊電王でも架橋上非架橋の苃は認められない。

〈3.2〉破壊電压の温度依存性 $1.0 \mathrm{~mm}$ 厚のポ リエチレンチューブを用いてアセトフェノン吸取試料 （試験時の败収量は 4 7\%) と，非吸収のオリジナル 試料の直流破坮電压の温度依存性を比校した。

試料枯各温度で最低 45 分保持後破壊試験芫行なっ

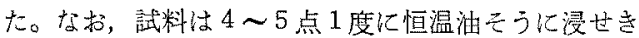
し，1点ずつ破壊試験を行なったため試料間の保持時 間は若干のずれがある。

奏駼結果第 4 四に示すが，オリジナル，吸收試料 と屯破填霄王级温度と其に低下する。しかし，アセ卜 フェノンを吸收した場合はオリジナルと比較して低温 領域ではほとんよ゙差がないが，常温付近以上になると 著しく低下することがわかった。

\section{〈3.3〉アセトフェノンの吸収量と直流破壊電圧}

$1.0 \mathrm{~mm}$ 及ざ $3.0 \mathrm{~mm}$ 厚のポリエチレンチューブを 用いてアセトフェノンの吸収量と直流破㘫電圧の関係 を調べた。吸取量の調節は浸せき温度，常温放置時闃 を变化させた。例えば， $1.0 \mathrm{~mm}$ 厚チューブの場会，

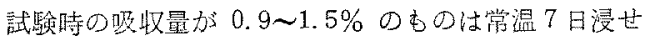
党後翌日試験，1.5 1.9\%のものは $80^{\circ} \mathrm{C} 4$ 日浸せき 嵈常温浸せき 3 日放置，4～7\% の屯のは $80^{\circ} \mathrm{C} 4$ 日浸

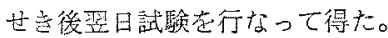

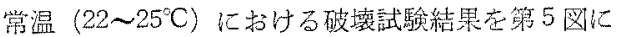

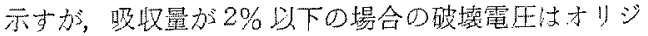
ナルよりやや低下する程度であるか，4〜7\%になると 著しく低下する。

しかし，常湿では低下しない1.5〜1.9\%吸收武料

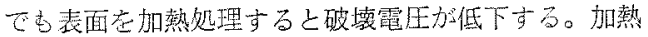
始理の方法はスズはく電極走巻かない裸の試粗口中央 付近約 $20 \mathrm{~cm}$ をガスバーナの弱い炎て約 3 分間方於

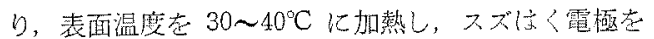

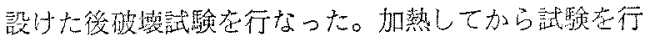
なうまでの時間は10〜20分で常温ふんい気中で行な

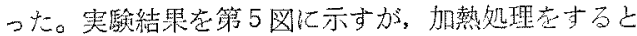
1. 5 1.9\% 吸収試料ても破壊電王力極端に低下する ことがわかった。また，比較として同じように加熱し

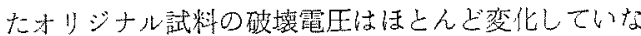
いことから，この特異な現象は吸収した微最のア七ト フェノンの影響上考えられる。

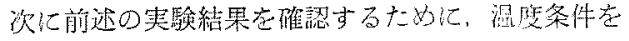

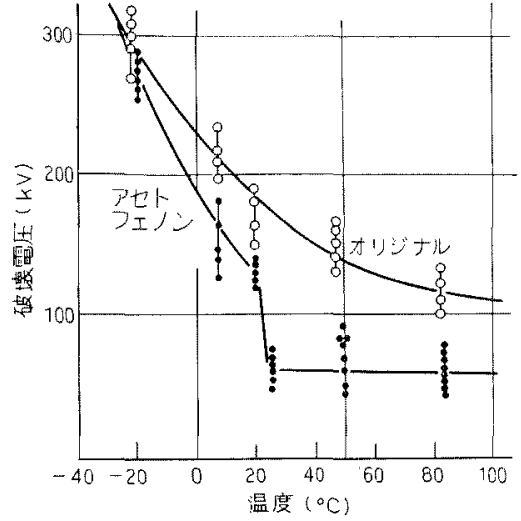

第 4 図アセトフェノン吸収ポリエチレン の直流破塤電压一温度特性

Fig. 4. DC breakdown voltage-temperature characteristics of acetophenone absorbed polyethylene.

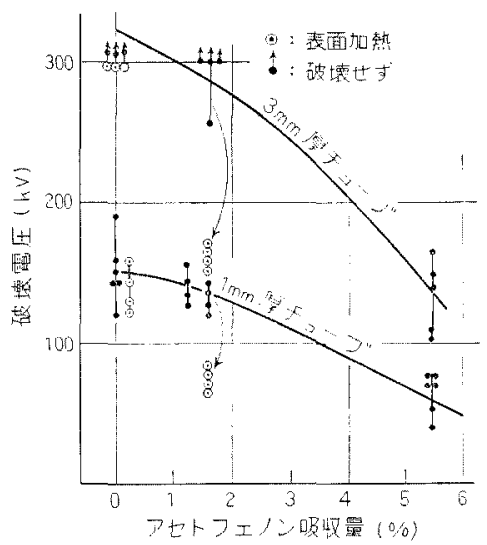

第 5 図アセトフェノン吸収ポリエチレン の破填霓在とアセトフェノン吸収量

Fig. 5. Relation between acetophenone content and DC breakdown voltage of acetophenone absorbed polyethylene.

はっきり決めた实験を行なった。実験岵 $1.5 \mathrm{~mm}$ 厚モ デルケーブルに約 $2 \%$ のア七トフェノン壳吸収させ，

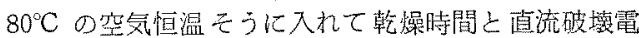
正の関係を調べた。な格，比較として交流破猿電㞋す 調べた。破䘫坛驗は常温て行なった。

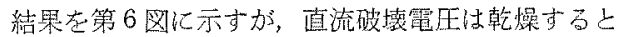


するとオリジナルポリエチレンと同等になるととがわ かった。これに対して交流ては蹎のようなミニマム 点はなく，乾燥すると破壊電压は低下し， その情で飽 和す当。

昭 $52-2$ 


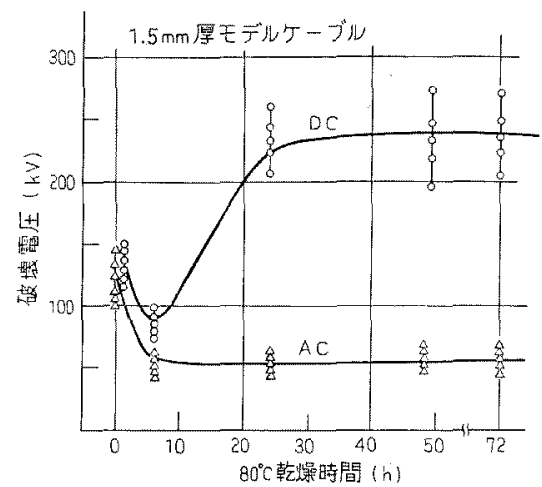

第 6 図了セトフェノン吸收架橋ポリチ



Fig. 6. Influence of drying condition on breakdown voltage of acetophenone absorbed crosslinked polyethylene cable.

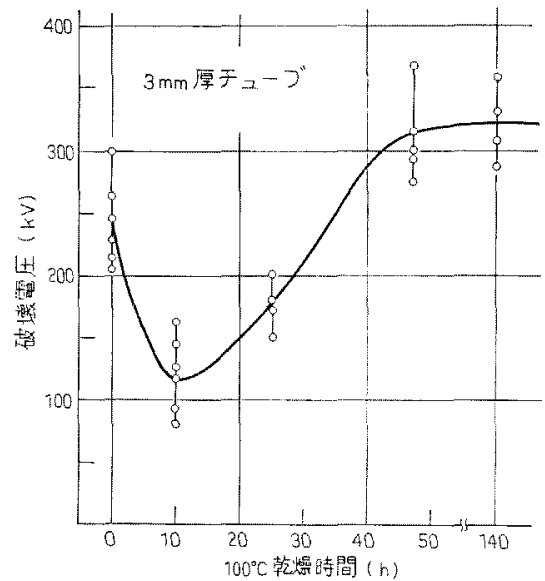

第 7 図アセトフェノン吸収ポリエチレン の幹燥上破溒電区

Fig. 7. Influence of drying condition on DC breakdown voltage of acetophenone absorbed polyethylene tube.

次に，同じくアセトフェノンを約 $2 \%$ 吸収させた $3 \mathrm{~mm}$ 厚チューブを用いて直流破淩電圧の $100^{\circ} \mathrm{C}$ 乾燥 効果を謂へた結果を第 7 図に示すが，やはりミニマム 点が現われ，その值はアセトフェノンを完全に揮散せ しめた值に比べて約 $1 / 3$ 近く低下する。

筆者は前起 ${ }^{(3)}$ で交流においてはアセトフょノンの絶 縁体中の分布よりむ表面比じみ出ているか否加の方 がより大さい影望をむたらすてとを述べた。しかし， 今回の実験では直流ではアセトフェノンの服収量だけ ではなく，絶縁体中の分布咕大きい影響を及ぼしてい るととが考无られる。
〈3.4〉昇圧速度の影艟

$1.5 \mathrm{~mm}$ 厚の架橋ポリ エチンンケーブルを用いて昇圧速度が直流破溒電生に 及仿す影響について調べた。

実験はオリジナル及びアセトフェノン $4 \%$ 吸収武料 を用い，昇王速度を $2.7 \mathrm{~V} / \mathrm{s}, 5.5 \mathrm{~V} / \mathrm{s}, 50 \mathrm{~V} / \mathrm{s}, 500 \mathrm{~V} / \mathrm{s}$ の 4 段階比变えて導体正極性および負極性の常温汇お ける破溒試䮖を行なった。なお，2.7V/s 及び $5.5 \mathrm{~V} / \mathrm{s}$ の場合法破壊予想檤の $60 \%$ まで $500 \mathrm{~V} / \mathrm{s}$ で昇王し， 乞の後は $2.7 \mathrm{~V} / \mathrm{s}$ が $1 \mathrm{kV} 10$ 分ステップで， $5.5 \mathrm{~V} / \mathrm{s}$ が $1 \mathrm{kV} 3$ 分ステップの階段昇王法を用いた。

試験結果を第 8 図㐾示すが，ての結果，オリジナ

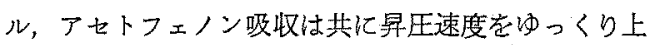
げるよ破壦電仕は低下し，しかも正極性，負極性の差 が小さくなる傾向を示す。しかし，昇圧速度による破 壊電圧の変化捄よび極性効果はアセトフェノン吸収の 方がオリジナルよりひ小さいと言える。

特海开压速度が遅い之破垻電生が低下するのは，交 流の $V-t$ 特性がこう配をむつのと同じ傾向と言える。

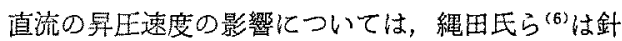
電極を用いてポリェチレンのトリ一発生電圧と昇圧速 度の関係を調べた結果，昇圧速度が遅いとトリ一発生 電王加高くなり，この原因は空間電荷によるものと説 明している。

今回筆者が行なった実験は全く逆の結果となってい るが，てれは試料の電極形状（釗電極とケーブル状サ ンプル），試験方法(トリ一発生と破壊電王）の相違に よるすのの他に空間電荷の勎果以上にこれを打消すよ うな劣化機構があることが考えられる。しかし，詳細 な譏構は現状ては明らかでない。

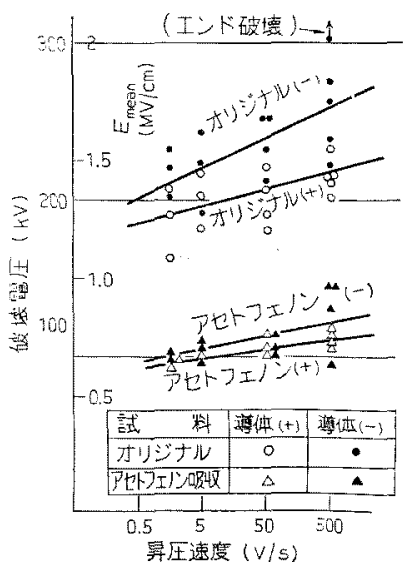

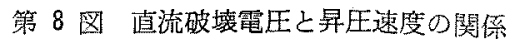

Fig. 8. Relation between DC breakdown voltage and rising speed. 


\section{〈3.5〉極性反転の影響 $1.5 \mathrm{~mm}$ 厚の架橋沓り} エチレンモデルケーブルを用いて常温における極性反 転の寒験を行なった。

試料はオリジナルとアセトフェノン 4 \% 吸収試料老

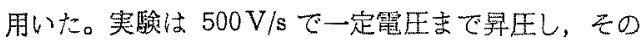
電正を 10 悡間保持した㣪，極性反転した。反転の方 法は高王電極とアース露極を機械的に反転した。すな わち，例えげ導体が高圧正極性の場合，反転後は導体 が接地，外部電極が高圧正極性となる。スタート䨮圧 は単極性の破壞䨘压の $50 \%$ 值で, ステップアップの 間隔は $10 \mathrm{kV}$ である。

実験結果を第 9 図に示すが，乙の結果，オリジナル 試料は極性反転により破堎電压が著しく低下するが， (一)加ら(十)上，(十)加ら(一)の差はほとんどない。 アセトフェノン吸収試料の破壊電生は極性反転して屯 ほと九ど変化しない。

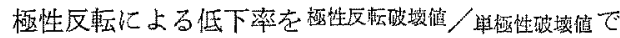
現わすとオリジナルの場合，(+)から(一)が 0.65， (一)加ら(十)驾 0.55 になり，アセトフェノン吸收ポ リエチレンは1である。

山田氏ら (2)はポリエチレン及び架橋ポリエチレンの 極性反転特性店調べだ結果，いずれむ極性反転に上り 低下の傾向があり，乙の原因は反転前汇䉓極前面に木 モチャージの蓄積があるたためと考察している。

\section{4. 実験結果の考察}

ポリエチレン及び架橋ポリエチレンケーブルの直流

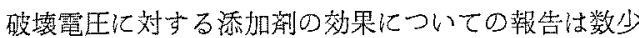

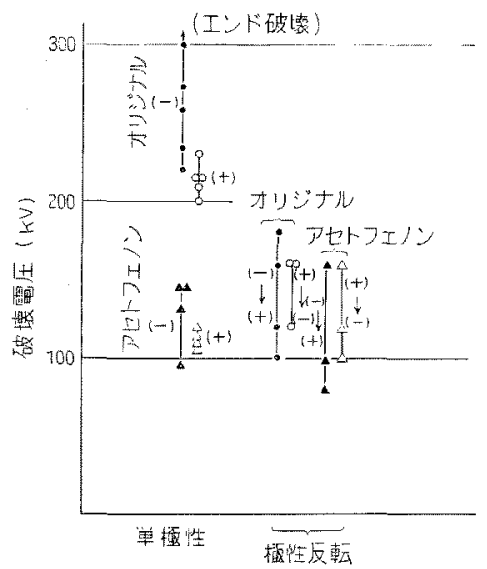

第 9 图アセトフェノン吸收架橋术リエチ

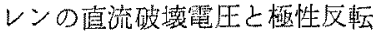

Fig. 9. Relation between DC breakdown voltage and polarity reversal.

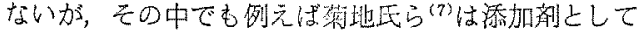
带電防止戍やコロナ防止剂定混入した場合，直流破壊

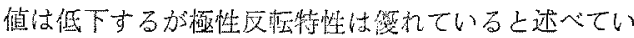
る。

宮入氏ら ${ }^{(8)}$ は指りエチレンに带電防止剂を暴加して 絶縁破燷強度に及济す温度, 添加量, パルス幅の㳖存 性について榆討した結果，添加ポリエチレンの絶縁破 壞北熱破填の理諭によって説明できると述べている。

添加片とは若千異なるが，天川无ら(9)はポリエチレ ンを酸化する之高温頒域で直流，パルス共化䋓緑破壊 強度が低下し，低温領域では反対に高くなると述べて いる。

篚者は今回アセトフーノンといくつかの液体迮ポリ

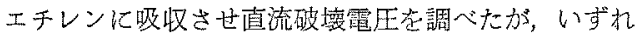
あ向上は認多られなかった。

今回の䒠験でアセトフ+ノン吸取ポリエチレンの破 壊電圧の温度依存性法 $20^{\circ} \mathrm{C}$ 付近以上になると著しく 低下した。

筆者はすすで交流の場合は直流上逆に $20^{\circ} \mathrm{C}$ 以上に なると破塄電生が向上するととを報告した(3)。乙の原 因は $20^{\circ} \mathrm{C}$ 付近でアセトフェノンが結昆化し，体皘抵 抗率加增加(約 $10^{9} \Omega \cdot \mathrm{cm}$ ) するためである。すなるち $20^{\circ} \mathrm{C}$ 队上になると体積抵抗率の但い液体（約 $10^{6} \Omega$. $\mathrm{cm})$ となるので，ポリエチレン中に一様红分布してい る場合は表面ににじみ出，ポリエチレンの表面抵抗が 下がり，部分放電が起りにくく圾る。このため交流破 畷電圧が向上することを前報(3)で日らかにした。

アセトフェノン吸収ポリエチレンの直流破壊電压の 温度特性すとの結晶化利近で变化するが，破壊電压が 低下するのは，ここでは体皘抵抗率の低い液体である ことが一つの条件であると考无られる。

そこで，液体のアセトフェノン吸収ポリエチレンの 破壊原因について考察する。まず，ポリエチレンにア セトフェノンを吸収させた場合の破壊電圧の低下には アセトフェノンの吸叹量だけではなく，絶縁体中の分 布の状態む大きい影響を及玨していることは第 5 図〜 第 7 因の実験加ら推定できる。そこで，实際に䋓縁体 中のアセトフェノンの分布を調へてみた。

実験は先の第7图で用いたアセトフェノンを吸収さ せた $3 \mathrm{~mm}$ 厚チューブを $100^{\circ} \mathrm{C} 10$ 時間， 24 時間， 48 時間空気恒温そうで乾懆した㖟，それぞれ厚さ 0.3 $\sim 0.5 \mathrm{~mm}$ に切断して重量测定し，百に大の試料を十 分乾燥して重量測定し，重量变化老求的て厚さ方向の 吸收量の分布を調べた。

結果第 10 図仁示すが，アセトフュノンは絶縁体 の雨側加ら次第に抜けていくこ上がわ加った。また， 




第10园 絶緑体中のアセトフェノンの分有

Fig. 10. Distribution of acetophenone in insulation.

陚料の表面に $0.01 \mathrm{~mm}$ 厚のスス゚はくを $1 / 2$ 重䄪 1 層 淃き，導体侧に $10 \mathrm{sc}$ のシリコーン油を封入し，10.0 $\mathrm{C}$ 24 洔間乾燥したすのの吸收量の分布を同じ第 7 图 に示す。この結果，アセトフェノンの抜ける量注スズ はくを巻かない試料に比べると表面の抜け方が著しく 小さいことがすかる。

てれらの夷験加ら，高温時の破填試跧や次化示す高 溢時の体皘抵抗率は，スズはくを巻いて测定している ためアセトフェノン絶緑体中にほぼ均一代詰まって いると推定できる。

一方，アセトフェノンを 4 5\% 吸取したポリェチ レンの体積抵抗率 ( $1 \mathrm{kV} ， 1$ 分值)を, 厚さ $0.25 \mathrm{~mm}$ のポリエチレンチューブ（電極長 $2 \mathrm{~m}$ ) を用いて测定 した。温度保持時間は 45 分とし，電生は導体㵝王 負極性を印加した。結果を第 11 図纪示すが，了セ卜 フェノンを吸収したポリエチレンはオリジナルのポり エチレンと比較すると 2 けた以上の差がある。

一般に，複合誘電体の電压分担は第 12 図化示す上 うなモデル汇おいて誘電率 $\left(\varepsilon_{1}, \varepsilon_{2}\right)$, 導電率 $\left(\sigma_{1}, \sigma_{2}\right)$, 厚 さ $\left(d_{1}, d_{2}\right)$, 電界 $\left(E_{1}, E_{2}\right)$ とし, 電圧 $V$ とする電 界 $E_{1}$ は(10),

$$
\begin{aligned}
E_{1}= & \frac{\sigma_{2}}{\sigma_{1} d_{2}+\sigma_{2} d_{1}} V+\left(\frac{\varepsilon_{2}}{\varepsilon d_{2}+\varepsilon_{2} d_{1}}\right. \\
& \left.-\frac{\sigma_{2}}{\sigma_{1} d_{2}+\sigma_{2} d_{1}}\right) V \exp \left(-\frac{t}{\tau}\right)
\end{aligned}
$$

$E_{2}$ む同㥞な形となる。

普通，直流電圧印加での電压分担はので決定される ので

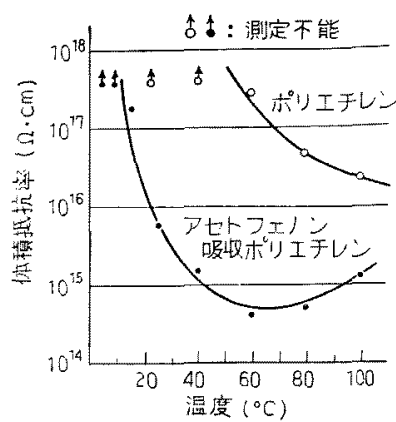

第 11 図 アセトフェノン吸収ポリエチレン の体皘抵抗率一温度特生

Fig. 11. Volume resistivity-temperature characteristics of acetophenone absorbed polyethylene.

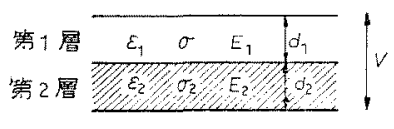

籍 12 図複合誘電侣つモデル

Fig. 12. Enlarged view of complexdielectric.

$$
\left.\begin{array}{l}
E_{1}=\frac{\sigma_{2}}{\sigma_{1} d_{2}+\sigma_{2} d_{1}} V \\
E_{2}=\frac{\sigma_{1}}{\sigma_{1} d_{2}+\sigma_{2} d_{1}} V
\end{array}\right\}
$$

ここで， 2 層の絶縁破壊の強さが同じとすると，例 えば $\sigma_{1}>\sigma_{2}$ ならば第 2 層の破壞が先侸起る。

そこて，前述のアセトフェノン吸収ポリエチレン試 料の表面付近のアセトフェノンが揮散して，いわゆる ドライバンドができた場合奆考党る。この埸合，高電 界に求时るのの值が不明なので正確な数值計算ばでき ないが，アセトフェノン吸収層とドライバンド層の $\sigma$ が仮に 1 けたの差があるとすると，(2)式加らドライ バンド層には約 1 けた高い電界がかかるととになる。

以上のこと加ら，アセトフェノン吸収ポリエチレン

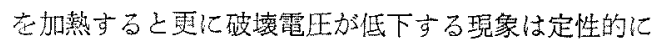
説明できる。

なお，交流の場合の電王分担は誘霓率によって決き るが，丁セトフェノン吸収ポリエチレンの誘電率は， 2.7 3.6 で, ポリエチレンの 2.3 に比へてそれほざ 差がないため，交流代括るドライバンドは直流はど 効かない。第6罒の結果はこれを衰付ける。

次に，アセトフェノンが一様行布しているポリエチ レンの破壞について考えてみる。不純物定添加するな どして導電率を增加させると熱破塤形式になることは 宮入氏ら ${ }^{(8)}$ も指摘しているが，今回行なったアセ卜フ 
ェノン吸収ポリエチレンあ熱破壊を示す結果が多く得 られた。

一般に熱破壊の基本式は次式で表わされている(10)。 $C_{v} \frac{d T}{d t}-\operatorname{div}(k \operatorname{grad} T)=\sigma E^{2}$

ここに，C。：体積比熱（ポリエチレンの場合

$2.23 \mathrm{~J} / \mathrm{cm}^{3} \cdot \mathrm{K}$ を埰用), $d T / d t$ : 単估時間あ

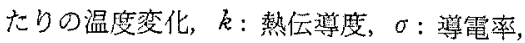

$E:$ 電界

すなわち，熱破壊はジュール熱が基本となっている ことから，電旦と試料の導電率によって決まるこし， 熱時定数があるので破復の時間遅れがあるととなどが 特㟨である。

電極などへの㳯放散定無視する上，(3)式上り温度 上昇は次のようになる。

$$
\Delta t=\sigma E^{2} / C_{v}
$$

また，交流の場合の誘霓体損失によって発生する熱は $\omega \varepsilon^{\prime} E^{2} \tan \delta$ であるので，温度上㫒は

$$
\Delta t=\frac{\omega \varepsilon^{\prime} E^{2} \tan \delta}{C_{v}}
$$

となる。

そこで,アセトフェノン吸収ポリエチレンの直流打

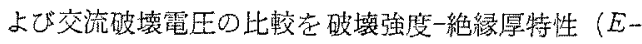
$d$ 特性)で示すと第 13 罒のようになる。

この図は今回㕂なったチューブ及びモデルケーブル のデータと，前回行なったフィルムのデータとををる めて作製した。この結果，アセトフェノン吸奴ポりエ チレンの場合，交流の破壦強度怔直流とほとんど同じ

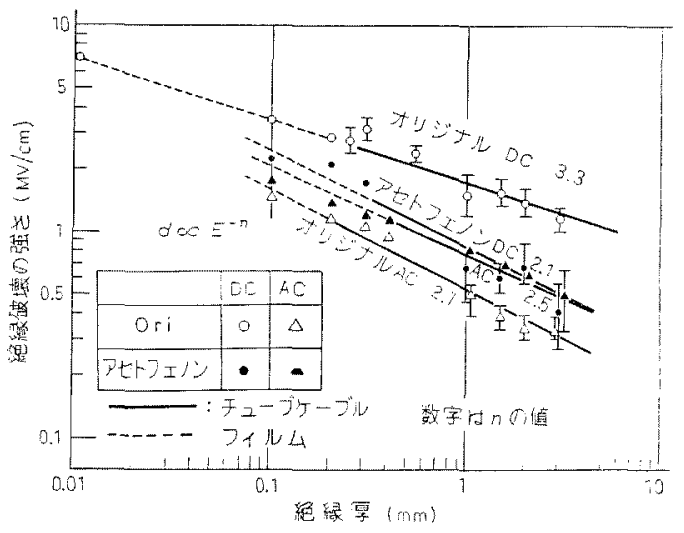

第 13 图了七トフェノン吸取ポリエチレンの $E-d$ 特性

Fig. 13. Breakdown strength-insulation thickness characteristics of acetophenone absorbed polyethylene.
であることがわかった。一般に交流の破境は部分放霓 に支配されることが知られているか゚，アセトフェノン 吸收ポリエチレンはアセトフュノンによって部分放電 が抑制される。往って，部分放笔破塂を抑制した交流 の值汃熱破壊であるとして檢討してみる。

こで, $\varepsilon^{\prime}: 3.6 \times 10^{-13} \mathrm{~F} / \mathrm{cm}, \tan \delta: 0.03, E:$ $10^{6} \mathrm{~V} / \mathrm{cm}$ として，(5)式より誘電体損による温筧上


よる温度上昇は $E: 10^{6} \mathrm{~V} / \mathrm{cm}, \rho: 10^{11} \Omega \cdot \mathrm{cm}\left(\rho-\frac{\text { 電 }}{2}\right.$ 王特性の测定結果より外をうして求めた）として計算 すると $4.5 \mathrm{~K} / \mathrm{s}$ となる。いず机の場合本温度上昇は少 ないが，試料の死状や局部電䪲を考愿する上，更心大 きくなるとしが若えられる。

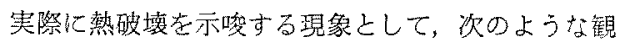
察結果㘦ある。ア七トフェノンを 4〜7\% 吸収ざせた

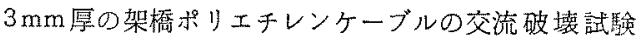
(10kV 1 時間ステップで界生) を行なったが，150〜 $160 \mathrm{kV}$ で表面温度が約 $20^{\circ} \mathrm{C}$ 上昇しているととを経䮖 した。

இ上のことから，アセトフェノンが一様分布してい る場合と，部分的にドライバンドができた場合の破壊 形態は唄なり，前者は䓡破壊，後者は抵抗分圧に上る 破境と推定されることが加った。

しかし，ここで実用的間題となるのは，ポリエチ レンや架橋ポリエチレンに液体を添加または吸収させ た場合は，比較的容易にドライバンドが形成されるこ とであり，長期間充满しているととの方がすしる少な いと言える。例えば，相溶性のある液体でも温度变化 や压力变化比上り絶縁体中老液体が移動するが，実用 面ではこのような復合形の断続分布が容易に起り得る ので注意が必柇である。

これらの液体の影響を防ぐ対策しして，淮体とポリ エチレンと組合さないことが当然必要てあるが，港吅 部として用いる埸合，動きにくい固体在添加すること が落えられる。

算者は，固体添加洲としてカーボンブラック䓘ポり エチレンに构り远むと特に愿肉において直流破壊電玉 が顕著に向上することを報告(11)したが，直流ケーブル

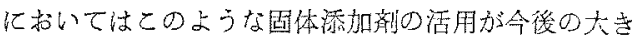
い課題となるであるう。

\section{5. ま と}

ポリエチレン及じ架橋ポリエチレンにアセトフェ， ンなどの液体を吸収させ，直流破瓘電王に及ぼす影響 な調へた。実験により得たことを要約すると次のし怙 りとなる。 
（1）アせトフェノン，OFケーブル油，DOSなど

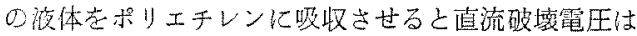
低下寸る。

(2) アセトフェノン吸取ポリエチレンの破㳖電生 一温㴔特性は $20^{\circ} \mathrm{C}$ 以上になる低下するが，乙の原因 はアセトフュノンの結晶性に関係があるように浡えら 枟。

（3）丁セトフェノンの吸取量が增えると共に破填 電压加低下する。しかし，破壤電压がそれはど低下し

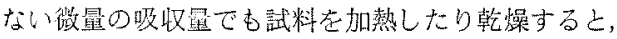

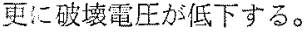

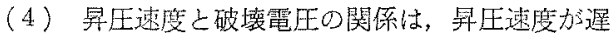
い上破壊電压が下がり，正極性，負極性の差驾小さく なっ瀬向定示す。

（5）アセトフェノン吸収ポリエチレンは極性反転 しても破腋電旺は低下しない。

（6）アセトフェノン吸収ポりェチレンの破壊電田 は交流上直流で差がない。

（7）これらの結果加ら，ア七トフェノン吸收ポリ エチレンの破䘫形態は 2 とおりあり，アセトフェノン が一椂分布している場合㹥热破壊，部分的にドライバ
ンドができた場合は抵抗分理による破填と考察した。 以上の結果は架欈ポリエチレン直流ケーブル及びそ の村属品の設計，实用化役役立つものと考えら礼る。

終りに，奏験にあたって㩊々御指導いただいた名古

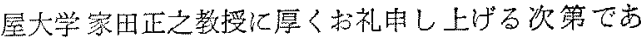
る。また，夷験を遂行していただいた当社研究開発本 部拝務浬 新内三干男, 宫内将和, 岩船俊彦の諸氏心深 〈感謝

(昭和 51 年 1 月 5 日受付，同 51 年8月 25 日再受付)

\section{文献}

（1）田中・坂本・大石：昭49策氮四学会速大 30

（2）例元出，山田・窝本：同上 31

（3）速水: 匴学誌 91，167 (昭 46-10)

(4) 速水: 雷気学全馀女誌 92-A, 27 (昭 47-7)

(5) 山田: 嚾49筺気四学公国大 873

（6）絸时・河村・家田: 同上 230

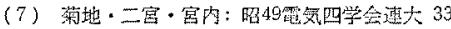

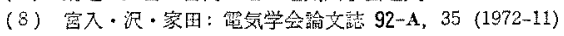

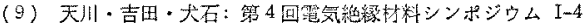
(昭 46)



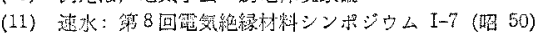

